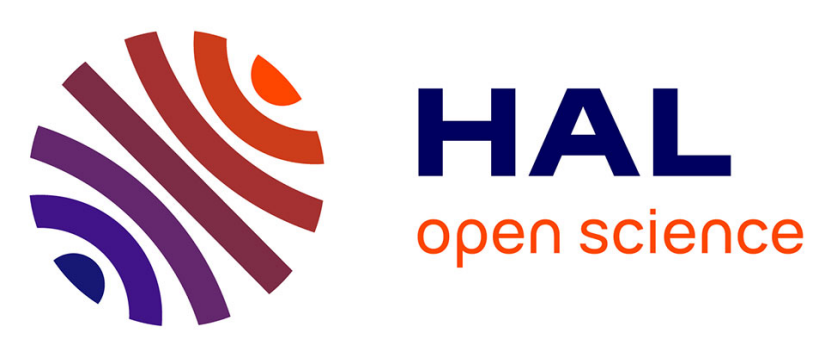

\title{
First experiments on the maternal transfer of metals in the cuttlefish Sepia officinalis
}

Thomas Lacoue-Labarthe, Michel Warnau, François Oberhänsli, Jean-Louis Teyssié, Ross Jeffree, Paco Bustamante

\section{- To cite this version:}

Thomas Lacoue-Labarthe, Michel Warnau, François Oberhänsli, Jean-Louis Teyssié, Ross Jeffree, et al. First experiments on the maternal transfer of metals in the cuttlefish Sepia officinalis. Marine Pollution Bulletin, 2008, 57 (6-12), pp.826-831. 10.1016/j.marpolbul.2008.01.042 . hal-00288870

\section{HAL Id: hal-00288870 https://hal.science/hal-00288870}

Submitted on 18 Jun 2008

HAL is a multi-disciplinary open access archive for the deposit and dissemination of scientific research documents, whether they are published or not. The documents may come from teaching and research institutions in France or abroad, or from public or private research centers.
L'archive ouverte pluridisciplinaire HAL, est destinée au dépôt et à la diffusion de documents scientifiques de niveau recherche, publiés ou non, émanant des établissements d'enseignement et de recherche français ou étrangers, des laboratoires publics ou privés. 
First experiments on the maternal transfer of metals in the cuttlefish Sepia officinalis

Thomas Lacoue-Labarthe ${ }^{1}$, Michel Warnau ${ }^{2 *}$, François Öberhansli ${ }^{2}$, Jean-Louis Teyssié $^{2}$, Ross Jeffree ${ }^{2}$, Paco Bustamante ${ }^{1}$

1 Littoral, Environnement et Sociétés (LIENSs), UMR 6250, CNRS-La Rochelle University, France

2 Marine Environment Laboratories, International Atomic Energy Agency (IAEAMEL), 4 Quai Antoine Ier, MC- 98000 Principality of Monaco

*Corresponding author:

Dr. Michel Warnau

Email: warnaumichel@yahoo.com; Phone: +336 62538327; Fax: +33 546458264 Current address: LIENSs, UMR 6250, CNRS- Univ. La Rochelle, 2 rue Olympe de Gouges, F-17000 La Rochelle, France 


\begin{abstract}
The aim of this study was to provide a first insight on the incorporation of 8 metals in the eggs of the cuttlefish Sepia officinalis via maternal transfer, using radiotracer techniques $\left({ }^{110 \mathrm{~m}} \mathrm{Ag},{ }^{241} \mathrm{Am},{ }^{109} \mathrm{Cd},{ }^{60} \mathrm{Co},{ }^{134} \mathrm{Cs},{ }^{54} \mathrm{Mn},{ }^{75} \mathrm{Se}\right.$ and $\left.{ }^{65} \mathrm{Zn}\right)$. The cuttlefish was fed daily with radiolabelled crabs for 2 weeks; it then started to spawn every 3 days. Among the 8 tracers, only ${ }^{110 \mathrm{~m}} \mathrm{Ag},{ }^{75} \mathrm{Se}$ and ${ }^{65} \mathrm{Zn}$ were significantly transferred to the eggs. The radiotracer distribution among the egg compartments showed that ${ }^{75} \mathrm{Se}$ and ${ }^{65} \mathrm{Zn}$ were accumulated mainly in the vitellus whereas ${ }^{110 \mathrm{~m}} \mathrm{Ag}$ was found in similar proportion in the vitellus and the eggshell. During the embryonic development, ${ }^{75} \mathrm{Se}$ and ${ }^{65} \mathrm{Zn}$ contained in the vitellus were progressively transferred to the embryo, likely to supply its metabolic needs in these essential elements. Although it has no known biological functions, Ag contained in both vitellus and eggshell was also transferred to the embryo. Overall, our results showed that transfer of $\mathrm{Ag}$, Se, and $\mathrm{Zn}$ does actually occur from a female cuttlefish to its eggs, at least during the last two weeks before spawning.
\end{abstract}

Key Words: Essential elements - non essential elements - radionuclide - vitellus cephalopod 


\section{Introduction.}

Metal enrichment of coastal waters mainly originates from river inputs (e.g., Chiffoleau et al., 1994). Exposure to pollutants is therefore of prime concern for biota inhabiting coastal areas, particularly during their early development, which is very sensitive to toxic effects of trace elements (e.g. Calabrese and Nelson, 1974, Warnau et al., 1996). The common cuttlefish Sepia officinalis lives offshore during the winter season and makes long reproductive migrations in spring to mate and to spawn in coastal waters (Boucaud-Camou and Boismery, 1991). The eggs are laid in shallow water areas and are therefore potentially subjected to chronic and/or acute contaminations. Overall, very little attention has been paid to the accumulation and toxicity of metals either on cuttlefish embryos or juveniles. Previous investigations on the behaviour of some metals during the egg development showed that $\mathrm{Ag}$, Co and $\mathrm{Zn}$ were accumulated within the embryo (Bustamante et al., 2002b, 2004) whereas Am, Cd, Pb, and V remained mainly associated with the glycoproteinic eggshell (Bustamante et al., 2004, 2006b, Miramand et al., 2006), thereby acting as a shield against potential toxic effects of the latter elements (Lacoue-Labarthe et al., 2008).

In addition to the direct contamination from the environment, the cuttlefish egg could also possibly suffer from a second contamination pathway, viz. the transfer of metals from the gravid female during the prespawning period. Indeed, the somatic tissues of the gravid cuttlefish female are partly used to produce the eggs (Guerra and Castro, 1994) and a fraction of their contaminant burden may therefore be transferred to the eggs and then to offspring. Indeed, despite their short life span, cuttlefish are known to 
strongly accumulate heavy metals in their tissues and particularly in the digestive gland (Miramand et al., 2006).

In fish, several studies have shown that essential metals (Peake et al., 2004) but also toxic elements (Sellin and Kolok, 2006) are maternally transferred to the eggs. Only few studies have considered the maternal transfer of metals in invertebrates and available information mainly concerns daphnids (e.g. Tsui and Wang, 2004, 2007, Lam and Wang, 2006). To the best of our knowledge, this issue has never been considered in cephalopods. The aim of this study was therefore to provide a first insight on the possible incorporation of 8 trace elements in cuttlefish eggs via the maternal pathway. This transfer and the subsequent element distribution in the eggs were studied using gamma-emitting radiotracers and highly sensitive nuclear detection techniques.

\section{Materials and Methods}

Five adult cuttlefish were collected by net fishing off Monaco in March and April 2006. They were acclimated to the laboratory conditions (constantly aerated open circuit; flux: $501 \mathrm{~h}^{-1}$; salinity: 37 p.s.u; temperature: $17 \pm 0.5^{\circ} \mathrm{C}$; $\mathrm{pH}$ : $8.0 \pm 0.1$; light/dark cycle: 12 $\mathrm{h} / 12 \mathrm{~h}$ ) for 2 weeks during which they were fed frozen smelt and alive green crabs Carcinus maenas. Females and males were then mixed in one 400-1 tank to obtain copulation. After the mating, the inseminated females were transferred to another tank and were then fed radiolabelled food (crabs C. maenas).

The radiolabelling of the crabs was carried out through feeding ad libitum for one week on mussels Mytilus edulis previously exposed for 6 days to natural seawater spiked with 
${ }^{110 \mathrm{~m}} \mathrm{Ag}\left(0.5 \mathrm{kBq}^{-1}\right),{ }^{241} \mathrm{Am}\left(0.1 \mathrm{kBq}{ }^{-1}\right),{ }^{109} \mathrm{Cd}\left(1.0 \mathrm{kBq}{ }^{-1}\right),{ }^{60} \mathrm{Co}\left(0.5 \mathrm{kBq} \mathrm{l}^{-1}\right),{ }^{134} \mathrm{Cs}$ $\left(0.6 \mathrm{kBq} \mathrm{l}^{-1}\right),{ }^{54} \mathrm{Mn}\left(0.2 \mathrm{kBq}^{-1}\right),{ }^{75} \mathrm{Se}\left(0.3 \mathrm{kBq}^{-1}\right)$, and ${ }^{65} \mathrm{Zn}\left(0.6 \mathrm{kBq} \mathrm{l}^{-1}\right)$.

After mating, the female cuttlefish were fed daily radiolabelled crabs during 10 days, then every 4 days to ensure a continuous exposure to the radiotracers until day 26 . After each feeding, the dorsal carapace and crab legs, which cuttlefish do not ingest, were removed as well as cuttlefish faeces in order to avoid radiotracers recycling through seawater. When females were not fed radiolabelled food, they each received daily a non-contaminated alive crab.

One out of the five females started to spawn at day 10 until day 38. Freshly laid eggs were periodically sampled, weighed and radioanalyzed. After gamma-counting, the eggs were dissected to determine the distribution of the radiotracers between the eggshell and the vitellus. At the end of the experiment, the female cuttlefish was sacrificed, weighed and dissected in order to determine the distribution of radiotracers among its organs and tissues.

The activity of the radiotracers was measured using a high-resolution $\gamma$-spectrometry system consisting of four coaxial Germanium (N- or P-type) detectors (EGNC 33-195R, Canberra ${ }^{\circledR}$ and Eurysis ${ }^{\circledR}$ ) connected to a multi-channel analyzer and a computer equipped with a spectra analysis software (Interwinner ${ }^{\circledR}$ 6). The detectors were calibrated with an appropriate standard for each counting geometry used and measurements were corrected for background and physical decay of the radiotracers. Counting times were adapted to obtain relative propagated errors less than $5 \%$. They ranged from $10 \mathrm{~min}$ to $30 \mathrm{~min}$ for whole eggs and from $10 \mathrm{~min}$ to $24 \mathrm{~h}$ for the dissected organs and tissues. 


\section{Results}

The activities of the different radiotracers in the crabs, in the gravid female cuttlefish and in its eggs are shown in Table 1. The crabs (viz. cuttlefish prey) displayed high activities in ${ }^{110 \mathrm{~m}} \mathrm{Ag},{ }^{109} \mathrm{Cd}$, and ${ }^{65} \mathrm{Zn}\left(26.6 \pm 16.8,69.2 \pm 41.7\right.$, and $29.1 \pm 16.0 \mathrm{~Bq} \mathrm{~g}^{-1}$ wet wt, respectively. The activities in crabs were below $7 \mathrm{~Bq} \mathrm{~g}^{-1}$ wet wt for the other radiotracers, ${ }^{241} \mathrm{Am}$ and ${ }^{134} \mathrm{Cs}$ being the less efficiently accumulated elements $(<0.5 \mathrm{~Bq}$ $\mathrm{g}^{-1}$ wet $\left.\mathrm{wt}\right)$.

Among the different radiotracers, ${ }^{241} \mathrm{Am},{ }^{134} \mathrm{Cs}$ and ${ }^{54} \mathrm{Mn}$ showed very low whole-body activities $\left(\leq 0.001 \mathrm{~Bq} \mathrm{~g}^{-1}\right.$ wet wt; Table 1$)$ in the female cuttlefish that was fed the radiolabelled crabs. In contrast to ${ }^{241} \mathrm{Am}$ for which the very low activities in the tissues did not allowed the determination of tissues distribution, ${ }^{134} \mathrm{Cs}$ was mainly found in the digestive system and ${ }^{54} \mathrm{Mn}$ in the genital system, which contained $97.7 \%$ and $62.7 \%$ of the whole-body activity, respectively (Table 2). The activity of ${ }^{60} \mathrm{Co}$ and ${ }^{75} \mathrm{Se}$ in the whole cuttlefish was below $0.01 \mathrm{~Bq} \mathrm{~g}^{-1}$ wet wt, and mainly present in the digestive system (94.9 and $76.3 \%$ of their whole-body activity, respectively; Table 2). It is worth noting that $19.4 \%$ of the ${ }^{75} \mathrm{Se}$ was found in the genital system of the female cuttlefish, of which $76 \%$ (17.7\% of the whole-body activity) were contained in the nidamental gland and $18 \%$ (3.5\% of the whole-body activity) in the ovary. Among the investigated tracers, ${ }^{110 \mathrm{~m}} \mathrm{Ag},{ }^{109} \mathrm{Cd}$ and ${ }^{65} \mathrm{Zn}$ displayed the highest activities in the cuttlefish tissues (0.12, 0.15 and $0.08 \mathrm{~Bq} \mathrm{~g}^{-1}$ wet $\mathrm{wt}$, respectively). They were mainly associated with the digestive system $(99.4,99.8$, and $98.0 \%$ of their whole-body activity) and particularly with the digestive gland (Table 2). 
Among the 8 elements, ${ }^{241} \mathrm{Am},{ }^{60} \mathrm{Co},{ }^{134} \mathrm{Cs}$ and ${ }^{54} \mathrm{Mn}$ were not significantly transferred to the cuttlefish eggs. In contrast, ${ }^{110 \mathrm{~m}} \mathrm{Ag},{ }^{75} \mathrm{Se}$ and ${ }^{65} \mathrm{Zn}$ were detected in the eggs with the following activities: $0.07 \pm 0.05,0.04 \pm 0.03$ and $0.20 \pm 0.13 \mathrm{~Bq} \mathrm{~g}^{-1}$ wet wt, respectively (Table 1). The radiotracer distribution among eggshell and vitellus showed that the greatest proportion of ${ }^{75} \mathrm{Se}$ and ${ }^{65} \mathrm{Zn}$ was associated with the vitellus (74.6 and $87.0 \%$, respectively) whereas ${ }^{110 \mathrm{~m}} \mathrm{Ag}$ was found in similar proportion in both compartments (i.e. 51.8 and $48.2 \%$ in the vitellus and the eggshell, respectively). However, the activity of ${ }^{110 \mathrm{~m}} \mathrm{Ag},{ }^{75} \mathrm{Se}$ and ${ }^{65} \mathrm{Zn}$ in the whole freshly laid eggs varied along the spawning period (Fig. 1). The first eggs were laid 10 days after the beginning of the exposure period and showed low radioisotope activities $\left(<0.1 \mathrm{~Bq} \mathrm{~g}^{-1}\right)$. The highest ${ }^{110 \mathrm{~m}} \mathrm{Ag},{ }^{75} \mathrm{Se}$ and ${ }^{65} \mathrm{Zn}$ activities $\left(0.14,0.12,0.43 \mathrm{~Bq} \mathrm{~g}{ }^{-1}\right.$, respectively) were measured in the eggs laid 14 days after the exposure beginning. From this time on, ${ }^{75} \mathrm{Se}$ and ${ }^{65} \mathrm{Zn}$ decreased progressively until the end of the spawning period despite the radiolabelled feeding at days 23 and 26 . In contrast, ${ }^{110 \mathrm{~m}} \mathrm{Ag}$ activity continued to increase in the eggs between the days 23 and 29.

\section{Discussion}

When fed with radiolabelled crabs, the activities of the different radioisotopes in the female cuttlefish tissues varied according to the elements, indicating their specific transfer and accumulation as previously reported (Bustamante et al., 2002b, 2004, 2006c), which was different than the one observed in the spawned eggs. Indeed, four groups of elements could be evidenced: (i) elements not incorporated in the adult cuttlefish tissues $\left({ }^{241} \mathrm{Am}\right)$, (ii) elements associated with the digestive system, strongly 
retained in the digestive gland and therefore not transferred to the eggs $\left({ }^{109} \mathrm{Cd}\right.$ and ${ }^{134} \mathrm{Cs}$ ), (iii) elements associated with the genital system but not transferred to the eggs $\left({ }^{54} \mathrm{Mn}\right)$, and (iv) elements transferred to the eggs independently of the adult tissues in which they are accumulated $\left({ }^{110 \mathrm{~m}} \mathrm{Ag},{ }^{75} \mathrm{Se}\right.$ and $\left.{ }^{65} \mathrm{Zn}\right)$.

Firstly, ${ }^{241} \mathrm{Am}$ was poorly incorporated in cuttlefish tissues and subsequently not detected in the eggs. This was obviously due to the very low accumulation efficiency of this element in the crabs used as food and to its subsequent low assimilation efficiency in the cuttlefish (Bustamante et al., 2006c). Secondly, ${ }^{109} \mathrm{Cd}$ and, to a lesser extent, ${ }^{134} \mathrm{Cs}$, were accumulated in cuttlefish tissues but were not transferred to the eggs. Both tracers remained associated with the digestive system, more particularly with the digestive gland which detoxification and storage role for these elements is well known in cephalopods (e.g. Martin and Flegal, 1975, Bustamante et al., 2002a, 2002b, 2006a). In fish, Cd has been shown to be transferred to eggs only above a given threshold body concentration that exceeds the metallothionein-binding capacity of the liver (Sellin and Kolok, 2006). In cephalopods, such a threshold concentration above which Cd would not be stored any longer in the digestive gland has not been shown. Since adult cuttlefish are known to accumulate large amounts of Cd (e.g. Bustamante et al., 2002a), further studies to verify that this threshold hypothesis would hold true for cuttlefish would be most informative to assess possible risk for offspring.

Similarly to ${ }^{109} \mathrm{Cd}$ and ${ }^{134} \mathrm{Cs},{ }^{54} \mathrm{Mn}$ was not transferred to the eggs, but in contrast to the former elements, ${ }^{54} \mathrm{Mn}$ was mainly accumulated in the genital system of the cuttlefish, more particularly in the nidamental gland. A previous study has reported that in immature cuttlefish this metal was mainly concentrated in the digestive gland and the 
cuttlebone (Miramand and Bentley, 1992), suggesting that the target organs of Mn may change with the reproductive stage of the females.

Finally, ${ }^{110 \mathrm{~m}} \mathrm{Ag},{ }^{75} \mathrm{Se}$ and ${ }^{65} \mathrm{Zn}$ were mainly distributed in the digestive system of the adult female and were the only elements that were transferred to the eggs efficiently. Se and $\mathrm{Zn}$ are essential elements that are well-known to be maternally transferred by metabolic mechanisms that depend on the sexual maturation (Montorzi et al., 1995, Unrine et al., 2006, Tsui and Wang, 2007). In contrast, Ag has no metabolic role and its transfer to the eggs could represent a maternal depuration mechanism.

In cuttlefish, $\mathrm{Zn}$ and Se are stored in the digestive gland (Miramand and Bentley, 1992) and could be a) directly used in the synthesis of yolk proteins and/or b) transferred to the genital system during the sexual maturation. $\mathrm{Zn}$, which is bound to the vitellin, is incorporated in the vitellus during the vitellogenesis (Montorzi et al., 1995). According to the latter authors, the vitellin precursor, i.e. vitellogenin, is synthesized in the cuttlefish digestive gland and then transferred to the oocytes, resulting in a concomitant transfer of $\mathrm{Zn}$. Hence ${ }^{65} \mathrm{Zn}$ measured in the egg vitellus in our study could similarly originate from the ${ }^{65} \mathrm{Zn}$ that was found to be stored in the digestive gland of the gravid female. This would also explain the very high $\mathrm{Zn}$ amounts recorded in oocytecontaining ovaries from mature female cephalopods collected in the field. For example, in the squid Illex argentinus, Gerpe et al. (2000) reported $1056 \pm 73 \mu \mathrm{g}$ wet wt of $\mathrm{Zn}$ in the gonad vs. $4.5 \pm 2.6 \mu \mathrm{g}$ in the digestive gland.

Previous works have shown that $\mathrm{Zn}$ concentrations in the cuttlefish embryo were similar to those measured in the vitellus (Miramand et al., 2006). This suggests that the amount of $\mathrm{Zn}$ provided during the vitellogenesis could be sufficient to cover the embryo needs for its complete development. However, it has been shown that the embryo accumulated 
${ }^{65} \mathrm{Zn}$ from the dissolved phase during the last third of its development period (unpublished data). Moreover, juvenile cuttlefish display $\mathrm{Zn}$ concentrations that are two-fold higher than in embryos (Miramand et al., 2006), which suggests that embryos and hatchlings are highly dependent on this essential metal to fulfil their metabolic demands and that the maternal transfer could not completely supply these needs.

Se is an essential element known to be necessary to the proper synthesis and functioning of the glutathione peroxidase, which is a major cellular antioxidant enzyme (Bell et al., 1986). In cuttlefish eggs, Se is mainly found in the vitellus (75\% of the whole egg burden), indicating that specific processes occurred for the integration of this element in the egg. Maternal transfer of Se to the offspring is well documented in fish (Gillepsie and Baumann, 1986), reptilian (Unrine et al., 2006) and daphnids (Tsui and Wang, 2007). In the sturgeon Acipenser transmontanus, Se is bound to the vitellogenin, lipovitellin and phosvitin and is incorporated in the yolk platelets (Kroll and Doroshov, 1991) suggesting a Se transport as yolk proteins from the liver to the eggs via the blood (Unrine et al., 2006). Therefore, similarly to $\mathrm{Zn}$, Se is likely to be first accumulated in the digestive gland of the female cuttlefish and then transferred to the egg yolk. However, in our study, Se was also found in the nidamental gland, suggesting a possible role of Se in the cephalopod egg laying processes.

Finally, contrasting to ${ }^{75} \mathrm{Se}$ and ${ }^{65} \mathrm{Zn},{ }^{110 \mathrm{~m}} \mathrm{Ag}$ was equally distributed between the vitellus and the eggshell which suggests its integration in the egg through both the yolk components and the nidamental gland involved in the eggshell production. In our study, $99 \%$ of the Ag body burden of the gravid female was stored in its digestive gland, which is in accordance with previous field findings (e.g., Miramand and Bentley, 1992, Miramand et al., 2006). In addition, it has been shown that digestive gland $\mathrm{Ag}$ is 
progressively translocated to the genital system (Bustamante et al., 2004), suggesting that maternal transfer could be an elimination pathway for a substantial part of the $\mathrm{Ag}$ previously accumulated in the digestive gland.

Radiotracer activities counted in the first laid eggs showed that metals were already transferred from the mother to the eggs in 10 days. This indicates that metal incorporation occurred in the proximal oviduct, where fully grown oocytes are kept before spawning (Zatylny, 2000) and implies that maternal transfer of metals is possible in eggs that are at the end of the vitellogenesis process and out the ovary.

The activity of ${ }^{65} \mathrm{Zn}$ and ${ }^{75} \mathrm{Se}$ increased in the newly laid eggs during the first 4 days of spawning. This could be due to a) the obvious longer time spent in the genital tract by the eggs spawned later and/or b) the fact that cuttlefish oocytes undergo an asynchronous maturation (Dhainaut and Richard, 1976). In the latter case, the eggs that were laid later might have been in an earlier maturation stage when the female cuttlefish started to be fed radiolabelled crabs. Hence, the incorporation of the radiotracers could have been more important if the vitellogenesis was not yet completed.

After this 4-day period of increase of the tracer activities in the eggs, ${ }^{65} \mathrm{Zn}$ and ${ }^{75} \mathrm{Se}$ slowly decreased in the new laid eggs until the end of the spawning period. This was due to the fact that, after day 17 , the daily radiolabelled feeding was stopped and followed by only two pulse feeding at days 23 and 26, which decreased the tracer amounts available for the maternal transfer. In addition, the later the female spawned the more frequent were the unfertilized eggs (viz. without oocytes and vitellus; Boletzky, 1998) found among the spawned egg pool.

The activity of ${ }^{110 \mathrm{~m}} \mathrm{Ag}$ in the spawned eggs showed a similar pattern than ${ }^{75} \mathrm{Se}$ and ${ }^{65} \mathrm{Zn}$ but consistently increased between days 23 and 28. This is to be related to the pulse 
feeding at days 23 and 26 and the fact that ${ }^{110 \mathrm{~m}} \mathrm{Ag}$ is rapidly transferred from the mother to the eggs, especially to the eggshell. This could also imply that a fraction of Ag can be directly incorporated in the eggs without intermediary storage step in the mother digestive gland. The rapid synthesis of the eggshell by the oviductal and nidamental glands which results in enwrapping the oocyte just before spawning can therefore be viewed as a rapid and efficient pathway of maternal transfer of this metal to the eggs.

In conclusion, among the 8 radiotracers present in the prey of the female cuttlefish, only two essential elements (i.e. $\mathrm{Zn}$ and $\mathrm{Se}$ ) and one non-essential metal (i.e. Ag) were transferred efficiently to the vitellus of the eggs. Moreover, Ag was accumulated in the eggshell, probably during its synthesis by the oviductal and nidamental gland secretions. The three elements were also detected in the juveniles (results not shown) after hatching, confirming the effective transfer from the mother to its offspring.

\section{Acknowledgements}

The IAEA is grateful for the support provided to its Marine Environment Laboratories by the Government of the Principality of Monaco. MW is an Honorary Senior Research Associate of the National Fund for Scientific Research (NFSR, Belgium). This work was supported by the IAEA and LIENSS.

\section{References}

Bell, J.G., Pirie, B.J.S., Adron, J.W. and Cowey, C.B. 1986. Some effects of selenium deficiency on glutathione peroxidase (EC 1.11.1.9) activity and tissue pathology in rainbow trout (Salmo gairdneri). British Journal of Nutrition 55, 305-311 
Boucaud-Camou, E. and Boismery, J., 1991. The migrations of the cuttlefish (Sepia officinalis L) in the English Channel. In: La Seiche - The Cuttlefish. 1st International Symposium on the Cuttlefish Sepia, Caen (France), 179-189 Centre de Publication de l'Université de Caen, France

Bustamante, P., Cosson, R.P., Gallien, I., Caurant, F. and Miramand, P. 2002a. Cadmium detoxification processes in the digestive gland of cephalopods in relation to accumulated cadmium concentrations. Marine Environmental Research 53, 227-241

Bustamante, P., Teyssié, J.-L., Fowler, S.W., Cotret, O., Danis, B., Miramand, P. and Warnau, M. 2002b. Biokinetics of zinc and cadmium accumulation and depuration at differents stages in the life cycle of the cuttlefish Sepia officinalis. Marine Ecology Progress Series 231, 167-177

Bustamante, P., Teyssié, J.-L., Danis, B., Fowler, S.W., Miramand, P., Cotret, O. and Warnau, M. 2004. Uptake, transfer and distribution of silver and cobalt in tissues of the common cuttlefish Sepia officinalis at different stages of its life cycle. Marine Ecology Progress Series 269, 185-195

Bustamante, P., Bertrand, M., Boucaud-Camou, E. and Miramand, P. 2006a. Subcellular distribution of $\mathrm{Ag}, \mathrm{Cd}, \mathrm{Co}, \mathrm{Cu}, \mathrm{Fe}, \mathrm{Mn}, \mathrm{Pb}$, and $\mathrm{Zn}$ in the digestive gland of the common cuttlefish Sepia officinalis. Journal of Shellfish Research 25, 987-993 Bustamante, P., Teyssié, J.-L., Fowler, S.W. and Warnau, M. 2006b. Contrasting bioaccumulation and transport behaviour of two artificial radionulides $\left({ }^{241} \mathrm{Am}\right.$ and ${ }^{134} \mathrm{Cs}$ ) in cuttlefish eggshell. Vie et Milieu 56, 153-156

Bustamante, P., Teyssié, J.-L., Fowler, S.W. and Warnau, M. 2006c. Assessment of the exposure pathway in the uptake and distribution of americium and cesium in cuttlefish 
(Sepia officinalis) at different stages of its life cycle. Journal of Experimental Marine Biology and Ecology 331, 198-207

Calabrese, A. and Nelson, D.A. 1974. Inhibition of embryonic development of the hard clam Mercenaria mercenaria, by heavy metals. Bulletin of Environmental Contamination and Toxicology 11, 92-97

Chiffoleau, J.-F., Cossa, D., Auger, D. and Truquet, I. 1994. Trace metal distribution, partition and fluxes in the Seine estuary (France) in low discharge regime. Marine Chemistry $47,145-158$

Dhainaut, A. and Richard, A. 1976. Vitellogenesis in Decapod Cephalopods: evolution of oocytes and follicular cells during genital maturation. Archives d'Anatomie Microscopique et de Morphologie Expérimentale 65, 183-208

Gerpe, M.S., de Moreno, J.E.A., Moreno, V.J. and Patat, M.L. 2000. Cadmium, zinc and copper accumulation in the squid Illex argentinus from the Southwest Atlantic Ocean. Marine Biology 136, 1039-1044

Gillepsie, R.B. and Baumann, P.C. 1986. Effects of high tissue concentrations of selenium on growth and reproduction by bluegills. Transactions of the American Fisheries Society 115, 208-213

Guerra, A. and Castro, B.G. 1994. Reproductive-somatic relationships in Loligo gahi (Cephalopoda: Loliginidae) from the Falkland Islands. Antarctic Science 6, 175-178 Kroll, K.J. and Doroshov, S.I., 1991. Vitellogenin: Potential vehicle for selenium bioaccumualtion in oocytes of the white sturgeon (Acipenser transmontanus). In: Williot, P. Acipenser, 99-106 Cemagref Publishers, Antony, France, 
Lacoue-Labarthe, T., Warnau, M., Oberhänsli, F.R., Teyssié, J.-L., Koueta, N. and Bustamante, P. 2008. Differential bioaccumulation behaviour of $\mathrm{Ag}$ and $\mathrm{Cd}$ during the early development of the cuttlefish Sepia officinalis. Aquatic Toxicology (in press) Lam, I.K.S. and Wang, W.X. 2006. Transgenerational retention and maternal transfer of selenium in Daphnia magna. Environmental Toxicology and Chemistry 25, 2519-2525 Martin, J.H. and Flegal, A.R. 1975. High copper concentrations in squid livers in association with elevated levels of silver, cadmium, and zinc. Marine Biology 30, 51-55 Miramand, P. and Bentley, D. 1992. Concentration and distribution of heavy metals in tissues of two cephalopods, Eledone cirrhosa and Sepia officinalis from the French coast of the English Channel. Marine Biology 114, 407-414

Miramand, P., Bustamante, P., Bentley, D. and Koueta, N. 2006. Variation of heavy metal concentrations $(\mathrm{Ag}, \mathrm{Cd}, \mathrm{Co}, \mathrm{Cu}, \mathrm{Fe}, \mathrm{Pb}, \mathrm{V}$, and $\mathrm{Zn}$ ) during the life cycle of the common cuttlefish Sepia officinalis. Science of the Total Environment 361, 132-143

Montorzi, M., Falchuk, K.H. and Vallee, B.L. 1995. Vitellogenin and lipovitellin: zinc proteins of Xenopus laevis oocytes. Biochemistry 34, 10851-10858

Peake, E.B., Locke, J.C., Tierney, L.L. and Kolok, A.S. 2004. Copper tolerance in fathead minnows : II. Maternal transfer. Environmental Toxicology and Chemistry 23, 208-211

Sellin, M.K. and Kolok, A.S. 2006. Cadmium exposures during early development: Do they lead to reproductive impairment in fathead minnows? Environmental Toxicology and Chemistry 25, 2957-2963

Tsui, M.T.K. and Wang, W.X. 2004. Uptake and elimination routes of inorganic mercury and methylmercury in Daphnia magna. Environmental Science and Technology 38,808-816 
Tsui, M.T.K. and Wang, W.X. 2007. Biokinetics and tolerance development of toxic metals in Daphnia magna. Environmental Toxicology and Chemistry. 26, 1023-1032 Unrine, J.M., Jackson, B.P., Hopkins, W.A. and Romanek, C. 2006. Isolation and partial characterization of proteins involved in maternal transfer of selenium in the western fence lizard (Sceloporus occidentalis). Environmental Toxicology and Chemistry 25, 1864-1867

Warnau, M., Iaccarino, M., De Biase, A., Temara, A., Jangoux, M., Dubois, Ph. and Pagano, G. 1996. Spermiotoxicity and embryotoxicity of heavy metals in the echinoid Paracentrotus lividus. Environmental Toxicology and Chemistry 15, 1931-1936 Zatylny, C., 2000. Etude du contrôle de la ponte chez la seiche Sepia officinalis L.: Applications à la conservation des stocks et au repeuplement dans l'Ouest Cotentin. PhD Thesis, Université de Caen Basse-Normandie, France. 
Table 1. Whole-body radiotracer activities in $\mathrm{Bq} \mathrm{g}^{-1}$ wet wt in the crabs used as food $(\mathrm{n}=7$; mean $\pm \mathrm{SD})$, the gravid female cuttlefish $(n=1)$, and the cuttlefish eggs $(n=250$; mean \pm $\mathrm{SD})$.

\begin{tabular}{lccc}
\hline & \multicolumn{3}{c}{ Activity $\left(\mathrm{Bq} \mathrm{g}^{-1}\right.$ wet wt $)$} \\
Female cuttlefish & Cuttlefish eggs \\
\hline${ }^{\mathbf{5 4}} \mathbf{M n}$ & $2.3 \pm 0.7$ & $<0.001$ & \\
${ }^{\mathbf{6 0}} \mathbf{C o}$ & $3.8 \pm 1.8$ & 0.009 & $<0.01$ \\
${ }^{\mathbf{6 5}} \mathbf{Z n}$ & $29.1 \pm 16.0$ & 0.077 & $<0.01$ \\
${ }^{\mathbf{7 5}} \mathbf{S e}$ & $6.7 \pm 3.4$ & 0.006 & $0.20 \pm 0.13$ \\
${ }^{\mathbf{1 1 0}} \mathbf{A g}$ & $69.2 \pm 41.7$ & 0.123 & $0.04 \pm 0.03$ \\
${ }^{\mathbf{1 0 9}} \mathbf{C d}$ & $26.6 \pm 16.8$ & 0.153 & $0.07 \pm 0.05$ \\
${ }^{\mathbf{1 3 4}} \mathbf{C s}$ & $<0.5$ & 0.001 & $<0.01$ \\
${ }^{\mathbf{2 4 1}} \mathbf{A m}$ & $<0.5$ & $<0.001$ & $<0.01$ \\
\hline
\end{tabular}


Table 2. Sepia officinalis. Distribution of the radiotracers (\%) among the different organs and tissues of the female cuttlefish fed radiolabelled crabs at the end of the spawning period. ${ }^{241} \mathrm{Am}$ data are not presented as its activity was too low to be determined accurately in the female tissues.

\begin{tabular}{lccccccc}
\hline Body compartments & ${ }^{54} \mathrm{Mn}$ & ${ }^{60} \mathrm{Co}$ & ${ }^{65} \mathrm{Zn}$ & ${ }^{75} \mathrm{Se}$ & ${ }^{109} \mathrm{Cd}$ & ${ }^{110 \mathrm{~m}} \mathrm{Ag}$ & ${ }^{134} \mathrm{Cs}$ \\
\hline Genital system & $\mathbf{6 2 . 7}$ & $\mathbf{0 . 2}$ & $\mathbf{1 . 2}$ & $\mathbf{1 9 . 4}$ & $\mathbf{0 . 1}$ & $\mathbf{0 . 5}$ & $\mathbf{1 . 6}$ \\
$\quad$ Ovary & 1.1 & 0.1 & 0.4 & 3.5 & 0.1 & 0.4 & 1.0 \\
$\quad$ Nidamental Gland & 60.0 & 0.1 & 0.7 & 14.7 & 0.1 & 0.1 & 0.2 \\
$\quad$ Accessory Nidamental Gland & 0.5 & $<0.1$ & 0.2 & 0.8 & $<0.1$ & $<0.1$ & 0.4 \\
$\quad$ Oviductal Gland & 1.1 & $<0.1$ & $<0.1$ & 0.5 & $<0.1$ & $<0.1$ & $<0.1$ \\
Digestive system & $\mathbf{3 2 . 7}$ & $\mathbf{9 4 . 9}$ & $\mathbf{9 8 . 0}$ & $\mathbf{7 6 . 3}$ & $\mathbf{9 9 . 8}$ & $\mathbf{9 9 . 4}$ & $\mathbf{9 7 . 7}$ \\
$\quad$ Digestive gland & 28.9 & 94.4 & 97.7 & 74.1 & 97.8 & 99.7 & 84.1 \\
Circulatory organs & $\mathbf{2 . 6}$ & $\mathbf{4 . 9}$ & $\mathbf{0 . 2}$ & $\mathbf{2 . 2}$ & $<\mathbf{0 . 1}$ & $<\mathbf{0 . 1}$ & $\mathbf{0 . 1}$ \\
\hline
\end{tabular}




\section{Caption to Figure}

Figure 1. Sepia officinalis. Radiotracer activities $\left(\mathrm{Bq} \mathrm{g}^{-1}\right.$ wet wt) in the freshly laid eggs during the spawning period $(O)$, and time of radiolabelled feeding $(\diamond)$ of the cuttlefish mother.

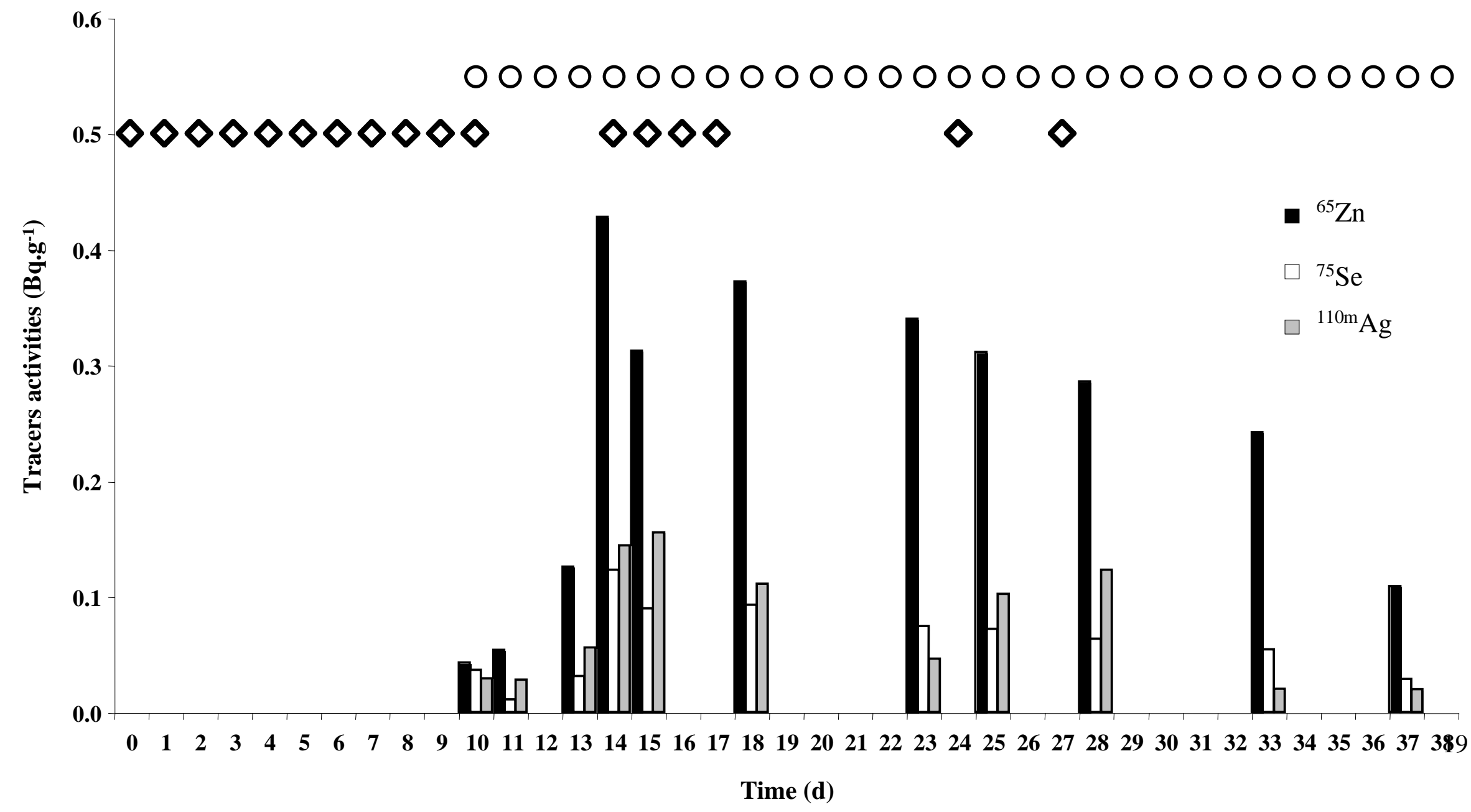

